\title{
Food photographs: practical guidelines II. Development and use of photographic atlases for assessing food portion size
}

\author{
Michael Nelson ${ }^{1, *}$ and Jóhanna Haraldsdóttir ${ }^{2}$ \\ 'Department of Nutrition and Dietetics, King's College London, Campden Hill Road, London \\ W8 7AH, UK: ${ }^{2}$ Research Department of Human Nutrition, Royal Veterinary and Agricultural \\ University, Rolighedsvej 30, DK-1958 Frederiksberg C, Copenhagen, Denmark
}

Submitted: 21 April 1998 Accepted: 8 August 1998

The main purpose of this paper is to provide practical advice on the development of photograph series of food portion sizes. The companion paper on validation in this issue outlines some of the theoretical concepts related to use of photographs when estimating portion sizes and the problems that may arise both in their use and in their validation.

It is useful to clarify a few terms that will be used throughout this paper:

- Photograph series: a set of photographs depicting different amounts of a particular food.

- Pbotographic atlas: a set of photograph series, usually bound together in a single volume.

- Portion: the amount eaten on any one occasion (first plus subsequent helpings).

- Serving: the amount of food served in a single helping.

\section{Before you proceed}

Before embarking on the development of a photographic atlas:

1. If possible, utilize existing photograph series or atlases which satisfy your requirements in terms of development and validation. A list of some atlases available is given in Table 1. You must ensure that appropriate validation has been carried out in a sample similar to that in which you plan to use the photographs. If the photographs suit your requirements but validation is necessary, see the companion paper on validation. The present paper may be useful, however, in highlighting some of the deficiencies which exist in the material available, and suggest modifications which could improve their usefulness.

2. If materials do not exist, make sure that you have the time and resources to do the job properly. Poorly constructed photograph series may do more harm than good, and use of only a few series in a long and complex assessment of diet may introduce bias in relation to particular food groups. You need to read the present paper in order to develop a series of photographs which will meet your requirements, and the companion paper in order to carry out appropriate validation.

Having decided that a new set of food photographs is required for your purposes, there are five steps which need to be followed.

Step 1: form a steering group. This group will advise on the final content and format of any photograph series or atlas developed. It should be made up of nutritionists, psychologists, sociologists and others who are involved in collecting information on food consumption and who are familiar with the food habits of the population in the country or region in which diet is to be assessed.

Step 2: consult widely. The researchers and dietitians who will use the photographs should be consulted about which foods to include. It is also necessary to consult the target population, as there may be foods which researchers regard as easy to measure but for which members of the population would find photographs helpful. The consultation process should address the issues listed below concerning the format and context of administration.

Step 3: use population-based data on types of food and ranges of portion sizes commonly consumed. Collect information from existing surveys or carry out dedicated surveys to identify the range of foods and the range of portion sizes which will need to be depicted. It is important to use weighed data where possible, as information based on household measures or food models may in itself be biased, particularly at the top and bottom end of the range.

Step 4. Select the foods to be included in the photograph series or atlas.

Step 5: repeat step 2. Ensure that the final selection of foods and portion size ranges for inclusion in the photograph series conforms with what is seen to be required.

It is vitally important in considering the design of the photograph series, in the administration of dietary 
Table 1 Some currently available photographic atlases of food portion sizes

\begin{tabular}{|c|c|c|c|c|c|c|c|c|c|}
\hline $\begin{array}{l}\text { Country } \\
\text { and } \\
\text { reference }\end{array}$ & Year & Title & $\begin{array}{l}\text { No. of } \\
\text { photo } \\
\text { series }\end{array}$ & Colour & $\begin{array}{l}\text { Portions } \\
\text { per series } \\
\text { (typically) }\end{array}$ & $\begin{array}{c}\text { Order of } \\
\text { presentation }\end{array}$ & $\begin{array}{c}\text { Series } \\
\text { per A4 } \\
\text { page }\end{array}$ & $\begin{array}{l}\text { Instructions } \\
\text { included }\end{array}$ & $\begin{array}{l}\text { Table of } \\
\text { contents }\end{array}$ \\
\hline $\begin{array}{l}\text { France }^{6} \\
\text { Portugal }^{7}\end{array}$ & $\begin{array}{l}1994 \\
1996\end{array}$ & $\begin{array}{l}\text { Portions Alimentaires } \\
\text { Manual de Quantificacao de } \\
\text { Alimentos }\end{array}$ & $\begin{array}{l}245 \\
110\end{array}$ & $\begin{array}{l}\text { Yes } \\
\text { Yes }\end{array}$ & $\begin{array}{l}3 \\
3\end{array}$ & $\begin{array}{l}\text { Increasing size } \\
\text { Varies }\end{array}$ & $\begin{array}{l}3 \\
2\end{array}$ & $\begin{array}{l}\text { Yes } \\
\text { Yes }\end{array}$ & $\begin{array}{l}\text { Yes } \\
\text { No }\end{array}$ \\
\hline Portugal $^{8}$ & 1996 & $\begin{array}{l}\text { Modelos Fotográficos para } \\
\text { Inquéritos Alimentares }\end{array}$ & 58 & Yes & 4 & Increasing size & 2 & No & No \\
\hline Portugal $^{4}$ & 1996 & $\begin{array}{l}\text { Registro Fotográfico para } \\
\text { Inquéritos Dietéticos }\end{array}$ & 71 & Yes & 3 & Decreasing size & 2 & Yes & Yes \\
\hline Poland ${ }^{9}$ & 1991 & $\begin{array}{l}\text { Album Porcji Produktów } i \\
\text { Potraw }\end{array}$ & 135 & Yes & 3 & Increasing size & 3 & No & No \\
\hline Sweden ${ }^{10}$ & 1997 & $\begin{array}{l}\text { Swedish Photographic } \\
\text { Atlas of Food Portion Sizes }\end{array}$ & 15 & Yes & 5 & Increasing size & 5 & Yes & Yes \\
\hline Finland 11 & 1985 & Annoskuvakina & 126 & Yes & 3 & Increasing size & 3 & Yes & No \\
\hline Russia $^{12}$ & 1995 & $\begin{array}{l}\text { Albom Portsiy Produktovi } \\
\text { Bljud (Album of Portions of } \\
\text { Food and Dishes) }\end{array}$ & 63 & Yes & 3 & Increasing or varies & 1 & No & No \\
\hline$U^{13}$ & 1997 & $\begin{array}{l}\text { Food Portion Sizes: A } \\
\text { Photographic Atlas }\end{array}$ & 98 & Yes & 8 & Increasing size & 1 & Yes & Yes \\
\hline EPIC ${ }^{14}$ & 1995 & $\begin{array}{l}\text { EPIC-SOFT Picture Book } \\
\text { for Estimation of Food Portion } \\
\text { Sizes }\end{array}$ & 140 & Yes & $4-6$ & Increasing size & 1 & Yes & Yes \\
\hline
\end{tabular}

assessment measures, and in clinical educational settings, that the distinction between 'portion' and 'serving' is made clear to both researchers and subjects (see definitions in the introduction).

\section{The format of the photographs}

The photograph series should be designed to minimize the error in estimates of portion size. The error is determined by the interaction between the format of the photograph series and the subjects' skills in describing portion size. Factors likely to influence this interaction are listed below.

1. Size of the image.

2. The number of portion sizes depicted.

3. The range of portion sizes depicted.

4. The interval between portion sizes depicted.

These first four items are related.

Size. The size of the images used in previous studies has ranged from single A4 photographs $(20 \times 29 \mathrm{~cm})$ to $6 \times 8 \mathrm{~cm}$. Eight $6 \times 8 \mathrm{~cm}$ images can be put on one A4 page, and Nelson et al. ${ }^{1}$ adopted this format as it provided the largest amount of useful information in the least amount of space.

Number. Previous studies have used between one and eight photographs when depicting a food. One is not recommended, as subjects have difficulty estimating fractions or multiples ${ }^{1}$. Three is typical ${ }^{2}$ (Fig. 1), but subjects may be tempted to choose the central image. An even number of photographs is probably better (either four, six or eight) (Fig. 2). Fewer photographs (e.g. four vs. eight) result in some loss of precision ${ }^{3}$.

Range. Information concerning the range of portion sizes to be depicted may be derived from national, ad boc or dedicated surveys. The ways in which data are reported (as servings or portions) may influence the final decision about the range to be adopted, and the choice may be driven by the type of dietary assessment being undertaken (e.g. portions for food frequency questionnaires, servings for prospective food checklists). Use a systematic approach (e.g. select the 5th to the 95th centile of reported serving size in a survey of adults). By depicting a wide range, very small or very large portion sizes will be included (including small second helpings), and the photographs may be appropriate for use with children as well as with adults.

Interval. The interval between images will be a product of the range divided by the number of images. A large interval will result in loss of information about actual amounts consumed. A very small interval (large number of photographs covering a very narrow weight range) may yield images so similar in appearance that subjects are unable to distinguish between them, leading to frustration and loss of attention. For greatest precision, it is desirable to find an interval 
$1 \mathrm{a}$

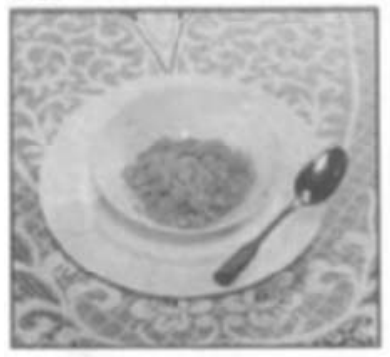

2a

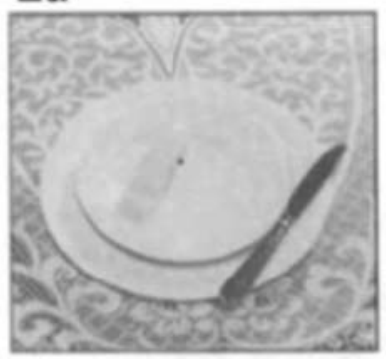

3a

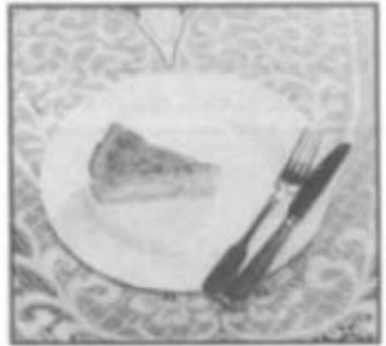

1b

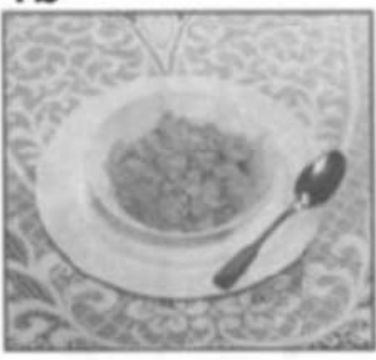

$2 b$

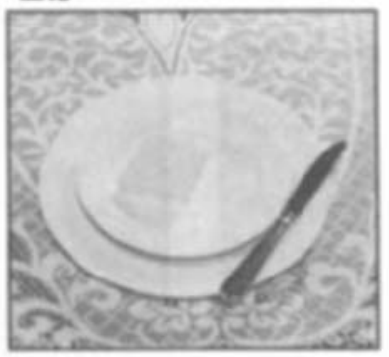

$3 b$

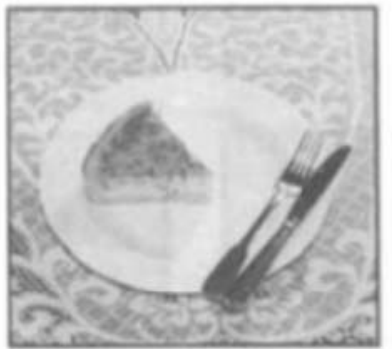

1c

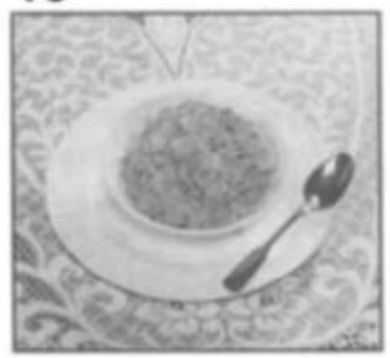

2c

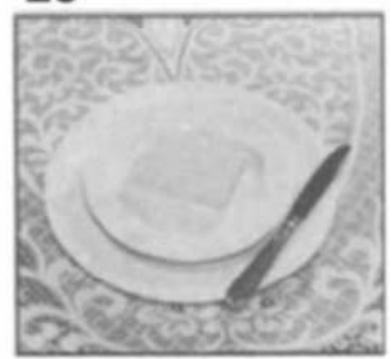

$3 c$

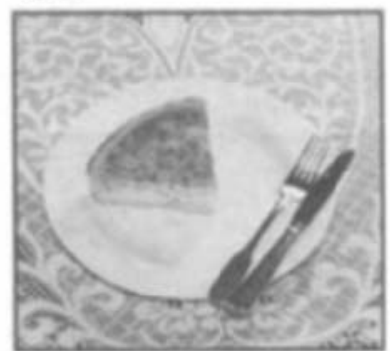

Fig. 1 Instructions and example of page from UK EPIC food diary ${ }^{2}$

which is just at the limit of subjects' ability to distinguish amounts depicted in adjacent images.

\section{The order of presentation.}

The most common order of presentation is from smallest to largest portion size in every photograph series. However, this may lead to bias if subjects mentally classify themselves as 'small' or 'large' eaters and select images at the extremes of the range without looking carefully at all of the images. Presentation of photographs in random order might help to overcome this problem, but such an approach would substantially increase respondent burden and is not recommended. Rather than being able to narrow down the range of response to a few images, subjects would have to scan enery image on a page in order to find the one which most closely described their usual portion or serving Ordering images from smallest to largest on some pages and largest to smallest on others might overcome the problem. No research has yet investigated whether the order of presentation of the images affects validity.

6. Labels used.

Images should be labelled with numbers or letters. These should be clear but not so large or conspicuous as to obscure or distract from the appearance of the food in the photograph. Names of foods, and labels such as 'small', 'medium' and 'large' should not appear on the photographs.

7. The background and use of reference objects.

The background should be unobtrusive and neutral in character. Reference objects (e.g. plate, knife and fork or other cutlery) should be included in every 

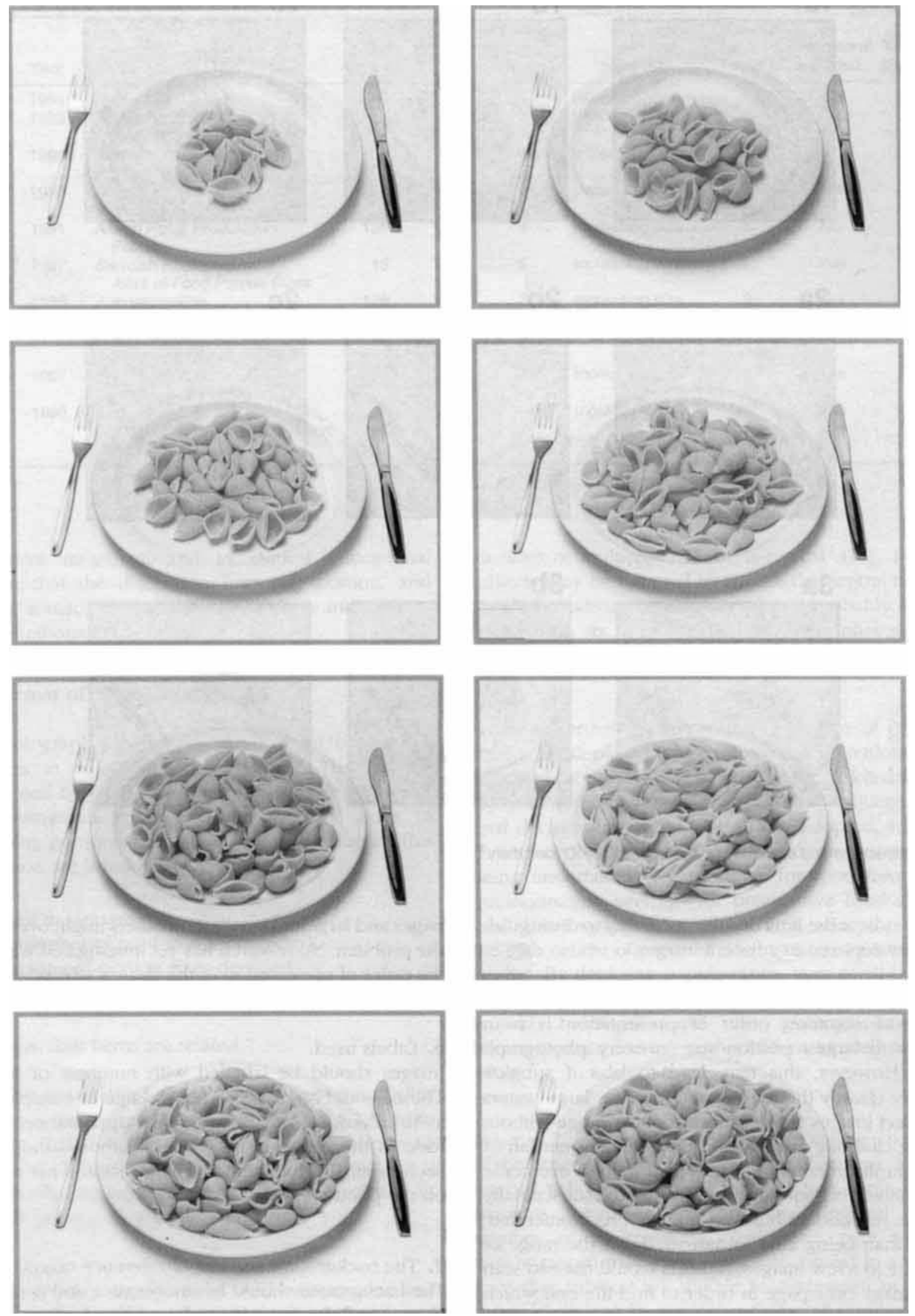

Fig. 2 Example of page from UK photographic atlas of food portion sizes ${ }^{14}$ 
photograph and also provided to subjects as real objects or life-size photographs so that subjects can relate the scale of food images in the photograph series to something which is present in reality.

\section{Colour or black and white.}

In previous research ${ }^{1}$ there was no difference between colour or black and white photographs relating to errors in the estimation of portion size. Subjects did report finding the colour photographs more interesting to look at, however, and this may help to promote good rapport and better concentration in long interviews (e.g. diet history).

9. One food or several foods on one plate.

Some photograph series have presented more than one food on a plate (e.g. Galeazzi et al. ${ }^{4}$ ). While this approach allows a wider range of foods to be depicted using fewer photographs, the range of portion sizes shown will inevitably be limited. This may ultimately be confusing for subjects who eat foods in combinations other than those illustrated.

\section{The foods to be included}

There are two basic questions that need to be answered when deciding on which foods are to be included in an atlas:

1. For which foods are photographs really necessary?

2. How many foods are to be included?

Foods which should not be included. Many foods (biscuits, yogurt in pots, etc.) are available for purchase in quantities that are easily identified from descriptions and which do not require photographs to improve estimation of portion size. These foods should not be included in an atlas:

- because their inclusion is likely to make the atlas more expensive, and

- subjects should not be asked to use photographs (a time-consuming procedure) if it is possible for them to quantify amounts accurately using descriptions alone.

Foods which should be included. Foods which should be included in an atlas are those that vary in portion size along a continuum from very small to very large, or that are irregular in shape or size and are not available in commercially standardized amounts. Foods differ in ways which will affect how well subjects are able to utilize photographs to estimate portion size. Table 2 summarizes the characteristics of foods and describes the nature of the judgement needed to estimate portion size from photographs.

More research is required to assess differences in the precision of estimates of portion size from photographs relating to different classes of food. One basis for excluding foods from an atlas could be the size of the error associated with portion size estimate: those foods which have an error below a given cut-off point need not be included.

How many foods should be included? There is no simple answer to this question. The temptation is to include as many foods as possible, but the result may be that subjects spend time and effort looking at photographs which do nothing to improve the precision of the estimates of portion size or nutrient

Table 2 Characteristics of food and the judgement required to assess portion size from photographs

\begin{tabular}{|c|c|c|}
\hline Characteristic of food & $\begin{array}{l}\text { Judgement required to assess } \\
\text { portion size }\end{array}$ & Examples \\
\hline Foods served in stiff mounds & Area and depth of mound & Mashed potato, ice cream \\
\hline Food served in loose mounds & Area and depth of mound & $\begin{array}{l}\text { Peas, diced vegetables, } \\
\text { grated cheese }\end{array}$ \\
\hline 'Slippery food' & $\begin{array}{l}\text { Area and depth of food spreading across } \\
\text { plate }\end{array}$ & Spaghetti, other pasta \\
\hline Food served in sauce or gravy & $\begin{array}{l}\text { Area and depth of food spreading across } \\
\text { plate }\end{array}$ & Baked beans, stew \\
\hline Dry food served in bowl & $\begin{array}{l}\text { Area and depth of mound in bowl where } \\
\text { much of the food is hidden from view }\end{array}$ & Cornflakes \\
\hline Wet food served in bowl & $\begin{array}{l}\text { Depth of food in bowl where much of the } \\
\text { food is hidden from view }\end{array}$ & Soup, stew \\
\hline Food served in wedges or blocks & Area and depth of wedge or block & Pies, cakes \\
\hline Slices of food & Area and thickness of slice & Meat, bread, cheese \\
\hline Discrete pieces of different sizes & $\begin{array}{l}\text { Volume of irregularly shaped foods; } \\
\text { area and depth of pieces }\end{array}$ & $\begin{array}{l}\text { Meat chops, bread rolls, } \\
\text { fruit, pieces of potato }\end{array}$ \\
\hline
\end{tabular}


intake. There is a law of diminishing returns, and the over-riding rule should be to have the fewest number of foods represented which help to achieve the desired level of precision.

The number of foods to be included in an atlas thus relates to:

- the resources available for the development of an atlas

- the final price which researchers or clinicians will be asked to pay

- the purpose to which the atlas will be put (e.g. having an atlas which is convenient to post)

- the diversity of the diet to be assessed

- the extent to which some foods may provide adequate representation of a number of other foods which are similar in appearance ('equivalent' foods, e.g. photographs of roast potato to represent pieces of roast parsnip).

There may be problems in terms of subject acceptability relating to the visual representativeness of 'equivalent' foods, and also when assessing weights of equivalent foods if food densities are markedly different between 'equivalents' (e.g. bran flakes are much more dense than cornflakes).

Ultimately, no matter how many photograph series are prepared, a subject who eats mainly pre-packed foods in easily quantifiable amounts is likely to have a more precise estimate of intake than a subject who eats foods consistently difficult to assess and which rely on photographs for their description.

\section{The administration of the photographs}

There are several ways in which subjects may be asked to identify portion size using a photograph series:

1. They may be asked to say which photograph most nearly depicts the portion size of the food consumed (four photographs, four choices).

2. They may be allowed to choose a particular photograph or to indicate a portion size between two photographs (four photographs, seven choices).

3. They may be allowed to choose a particular photograph, indicate a portion size between two photographs, or indicate a portion size greater than the largest amount or less than the smallest amount (four photographs, nine choices).

4. They may be asked to use a visual analogue scale (VAS) which enables them to indicate portion size at any point along a continuum ${ }^{5}$. For a shorter series of questions (e.g. a questionnaire relating to principal sources of calcium) the VAS may be practical as well as more precise. For a longer series of questions (e.g. diet history) use of the VAS may become tedious and lead to a loss of precision due to loss of concentration or motivation.

The instructions given about how to use the photographs, and the ease with which these are understood, will also influence the response.

\section{Acknowledgements}

This paper has been written in consultation with many colleagues from the European COST99 group and the UK Nutritional Epidemiology Group, too numerous to mention individually but whose comments are greatly appreciated. The work was supported by the European Concerted Action COST99 'Food consumption and composition data (EUROFOODS)'.

\section{References}

1 Nelson M, Atkinson M, Darbyshire S. Food photography 1: The perception of food portion size from photographs. Br.J. Nutr. 1994; 72: 649-63.

2 Bingham SA, Gill C, Welch A, Cassidy A, Runswick SA, Oakes S, Luben R, Thurnham DI, Key TJA, L, Khaw KT, Day NE. Validation of dietary assessment methods in the UK arm of EPIC using weighed records and 24-hour urinary nitrogen and potassium and serum vitamin $\mathrm{C}$ and carotenoids as biomarkers. Int. J. Epidemiol. 1997; 26 (Suppl 1): S137S151.

3 Nelson M, Atkinson M, Darbyshire S. Food photographs improve estimates of nutrient intake in dietary surveys. Proc. Nutr. Soc. 1996; 56: 205A.

4 Galeazzi MAM, de Meireles AJ, de Toledo Viana RP, Zabotto $\mathrm{CB}$, Domene SAM. Registro Fotográfico Inquéritos Dietéticos. Ministry of Health. National Institute of Food and Nutrition, Goiânia, Portugal, 1996

5 Nelson $M$. The validation of dietary assessment. In: Margetts BM, Nelson M, eds. Design Concepts in Nutritional Epidemiology, second edition. Oxford: Oxford University Press, 1997.

6 Hercberg S, Deheeger M, Preziosi P. Portions Alimentaires. Manuel photos pour l'estimation des quantités. Institut Scientifique et Technique de la Nutrition et de l'Alimentation, Conservatoire National des Arts et Métiers, CNAM Paris. Candia Polytechnica, France, 1994.

7 Marques M, Pinho O, de Almeida MDV. Manual de Quantificacao de Alimentos. Curso da Ciencias de Nutricao de Universidade do Porto, Porto, Portugal, 1996.

8 Rombo M, Silveira D, Martins I, Cruz A. Modelos Fotográficos para Inquéritos Alimentares. Centro de Estudos de Nutricao do Instituto Nacional de Saúde, Lisboa, Portugal, 1996.

9 Szczyglowa H, Szczepanska A, Ners A, Nowicka L. Album Porcji Produktow i Potraw. Instytut Zywnosci i Zywienia, Warzawa, Poland, 1991 (available from the authors).

10 Matmallen. Livsmedelsverket. Uppsala, 1997 (available from the authors).

11 Haapa E, Toponen T, Pietinen P, Rasanen L. Annoskuvakirja (portion picture booklet). National Public Health Institute and the Department of Nutrition, University of Helsinki, 1985 (available from the authors).

12 Martintchik AN, Baturin AK, Baeva VS, Peskova EV, Larina TI, Zaburkhna TG. Albom Portsiy Produktov i Bljud (Album of Portions of Food and Dishes). Institute of Nutrition, Moscow, 1995 (available from the authors). 
13 Nelson M, Atkinson M, Meyer J. A Photographic Atlas of Food Portion Sizes. Ministry of Agriculture, Fisheries and Food, 1997 (available from MAFF Publications, ref. no. PB3006).
14 van Kappel AL, Amoyel J, Slimani N, Vozar B, Riboli E. EPICSOFT Picture Book for Estimation of Food Portion Sizes. International Agency for Research on Cancer, Lyons, France, 1995 (available from the authors). 